\title{
POLSKA W UNII EUROPEJSKIEJ - PROCES AKCESYJNY I PRIORYTETY POLSKIEJ POLITYKI W RAMACH UE
}

ABSTRACT Poland in the European Union - the accession process and the priorities of Polish foreign policy in the EU

This paper presents the reasons for Poland's accession to the EU - perceiving it as a modernization project and as a guarantee of Polish international safety. In the second part of the paper the authors analyze negotiations between Poland and the EU from a political and economic perspective. A number of information about the accession process is provided, as well as an explanation of the negotiation mechanism. The last part of the paper is an analysis of Polish Presidency of the European Union Council and a consideration of future priorities of Poland's policy in the EU.

KEYWORDS Poland, EU, Europe, integration, outlook

\section{WSTĘP. GENEZA CZŁONKOSTWA POLSKI W UE}

W 1939 r. Niemcy rozpętały II wojnę światową. To dość nietypowy początek tekstu poruszającego tematykę Unii Europejskiej, ale genezy UE należy szukać właśnie w tym momencie. W pierwszej połowie XX w. patriotyzm został zastąpiony przez nacjonalizm, który doprowadził do tragedii: I i II wojny światowej. W 1939 r. Niemcy podjęły wojnę nie tylko z powodów politycznych czy ideologicznych. Przyczyną były też spodziewane korzyści gospodarcze, jakie miała odnieść zwycięska Rzesza. Skąd więc pomysł na integrację europejską? Odpowiedź wydaje się oczywista - zjednoczenie miało być lekarstwem na pokusę prowadzenia kolejnych wojen. Europejska Wspólnota Węgla 
i Stali miała zagwarantować międzynarodową kontrolę nad niezbędnymi do podjęcia zbrojeń surowcami. Kolejnym celem było takie zespolenie gospodarek krajów członkowskich, by wojna między europejskimi państwami stała się po prostu nieopłacalna. W ten sposób zamierzano wyeliminować konflikty zbrojne z europejskiej rzeczywistości. Dziś, po niemal 70 latach od zakończenia największej w dziejach wojny, wiele osób uznaje pokój w Europie za coś tak naturalnego, że zapomina o tym największym dokonaniu integracji europejskiej. Dla współczesnego pokolenia Europejczyków pokój jest czymś tak oczywistym, jak strefa Schengen, program wymiany Erasmus czy wolność słowa. Tymczasem dla starszych pokoleń, które przetrwały II wojnę światową oraz miały olbrzymie problemy z utrzymywaniem kontaktów z krewnymi po drugiej stronie żelaznej kurtyny, do niedawna były to rzeczy niewyobrażalne. Dlatego warto przypomnieć słowa kanclerz Angeli Merkel skierowane do Bundestagu: Jeśli upadnie euro, upadnie Europa. [...] Pokój, jakim cieszymy się na kontynencie od 50 lat, nie jest dany raz na zawsze $e^{2}$. Nie jest pewne, że w razie upadku UE sytuacja na kontynencie będzie stabilna. Przykład byłej Jugosławii świadczy o tym, że stabilizacji i pokoju nie można być nigdy pewnym. Dlatego w najlepszym interesie Europy i jej mieszkańców jest istnienie Unii, która czyni wojnę po prostu nieopłacalną.

Polska do UE przystąiła w 2004 r. Jakie były tego powody? Przede wszystkim chęć wypełniania próżni, w jakiej Polska znalazła się po rozpadzie porządku jałtańskiego. Strategicznym oparciem przestał być Związek Radziecki, a partnerami handlowymi kraje byłego bloku wschodniego skupione w Radzie Wzajemnej Pomocy Gospodarczej (RWPG). Przystąpienie do UE można traktować jako próbę wydostania się z sytuacji powstałej po dezintegracji bloku wschodniego. Alternatyw brakowało - Federacja Rosyjska i niestabilne republiki postradzieckie nie oferowały Polsce niczego, co można było uznać za atrakcyjne. Próby stworzenia w Europie Środkowo-Wschodniej organizacji zbiorowego bezpieczeństwa (NATO-bis) czy współpracy gospodarczej (EWG-bis) albo się nie powiodty, albo w założeniu nie stanowiły alternatywy dla zachodnioeuropejskich projektów integracyjnych, jak w przypadku CEFTA ${ }^{3}$. Polska mogła dążyć do integracji z ówczesnymi Wspólnotami Europejskimi lub pozostać osamotniona między wschodem i zachodem Europy. Pierwsza droga wydawała się zdecydowanie bardziej atrakcyjna, nie bez znaczenia było także zapatrzenie Polaków w Zachód. Przez lata komunizmu kraje Europy Zachodniej jawiły się im jako oazy szczęścia i dobrobytu. Nie dziwi więc, że priorytetem wszystkich rządów po 1989 r. stało się dołączenie do tego grona. Hasła wyborcze prezydenta Lecha Wałęsy, obiecującego przeksztalcić III Rzeczpospolitą w drugą Japonię, czy Donalda Tuska, zamierzającego uczynić

12 X 2012 r. Norweski Komitet Noblowski przyznał Unii Europejskiej Pokojową Nagrodę Nobla za [...] trwajace ponad sześć dekad starania na rzecz pokoju, pojednania, demokracji i praw cztowieka w Europie. Cyt. za: The Nobel Peace Prize for 2012, [online] http://www.nobelprize.org/nobel_prizes/peace/ laureates/2012/press.html\#, 14 X 2012.

2 M. Ryba, Walka o Rzym, walka o euro, „Nasz Dziennik”, 15 XI 2011, [online] http://stary.naszdziennik.pl/ index.php?dat $=20111115 \&$ typ=po\&id=po13.txt, 4 IX 2012.

3 Środkowoeuropejskie Porozumienie o Wolnym Handlu; por. W. Roszkowski, Najnowsza historia Polski 1980-2002, Warszawa 2003, s. 160. 
z Polski „zieloną wyspę” na wzór Irlandii, przyczyniły się do sukcesów wyborczych tych polityków ${ }^{4}$. Pośrednio dowodzą one, jak bardzo Polacy pragnęli dorównać krajom zachodnim.

Kolejnym powodem, dla którego Polska chciała przystąpić do Unii, było postrzeganie członkostwa jako szansy modernizacyjnej dla kraju. W przeciwieństwie do państw „starej” Europy, w Polsce głównym motorem integracji nie było zagwarantowanie pokoju, a rozwój gospodarczy. Perspektywa rozwijającej się w ramach wspólnego rynku gospodarki, wspieranej funduszami unijnymi, przekonywała Polaków do idei zjednoczonej Europy5. Dążenie do integracji ze Wspólnotami Europejskimi było jednak okupione wymagającymi działaniami dostosowawczymi. Przedstawienie drogi do akcesji, ze szczególnym uwzględnieniem procesu negocjacji, pozwoli odpowiedzieć na pytanie o pożądane miejsce Polski w Unii Europejskiej, zarówno dzisiaj, jak i w przyszłości.

\section{NEGOCJACJE AKCESYJNE}

Negocjacje akcesyjne należy rozpatrywać jako znaczący element procesu integracji Polski ze Wspólnotami Europejskimi, a po 1993 r. z Unią Europejską ${ }^{6}$. Doprowadzenie do oficjalnego rozpoczęcia negocjacji w marcu 1998 r. zostało poprzedzone wymagającym okresem budowania wzajemnych relacji politycznych oraz handlowych. Dążenie do integracji ze Wspólnotami odbywało się w trudnych warunkach transformacji systemowej oraz gospodarczej, której powodzenie (lub jego brak) miało zasadniczy wpływ na siłę przetargową krajów kandydujących oraz na kształt samego procesu negocjacyjnego. Omówienie jego przebiegu w kontekście polskich starań o członkostwo w UE warto tym samym rozpocząć od przedstawienia drogi prowadzącej do otwarcia negocjacji.

\subsection{Droga do negocjacji}

Za początek procesu integracyjnego ze Wspólnotami Europejskimi (WE) można uznać nawiązanie stosunków dyplomatycznych Polski z Europejską Wspólnotą Gospodarczą (EWG), które nastąpiło we wrześniu 1988 r., jeszcze w realiach Polskiej Rzeczpospolitej Ludowej. Potwierdzeniem polskich aspiracji związanych z ustano-

4 Por. L. Wałęsa, Druga Japonia, „Tygodnik Powszechny” 2002, nr 30, [online] http://www.tygodnik. com.pl/ japonia/index.html, 4 IX 2012.

5 Opinie o skutkach integracji Polski z Unia Europejska i przebiegu negocjacji akcesyjnych. Komunikat z badań, Centrum Badań Opinii Społecznej, Warszawa 2000, s. 5-6.

6 Na mocy Traktatu o Unii Europejskiej (TUE) z 1992 r. powołano do życia Unię Europejską, która skupiała Wspólnotę Europejską, Europejską Wspólnotę Węgla i Stali oraz Euratom. Wraz z wejściem w życie Traktatu z Lizbony 1 XII 2009 r. Unia Europejska zastąpiła Wspólnotę oraz stała się jej następcą prawnym. Por. Wersja Skonsolidowana Traktatu o Unii Europejskiej, Dz. U. UE C 83 z 30 III 2010, art. 1. 
wieniem współpracy z państwami EWG było podpisanie Umowy w sprawie handlu oraz współpracy handlowej i gospodarczej z 1989 r. ${ }^{7}$ Umowa została przyjęta podczas zmian systemowych $\mathrm{w}$ Polsce, które spotkały się z aprobatą ze strony państw Europy Zachodniej. Wyrazem wsparcia dla zmian ustrojowych oraz demokratyzacji instytucji państwowych było powołanie programu PHARE, mającego na celu zapewnienie pomocy finansowej dla restrukturyzujących się gospodarek państw Europy Środkowo-Wschodniej (EŚW $)^{8}$. Do przyspieszenia niezbędnych zmian strukturalnych miało się przyczynić utworzenie Europejskiego Banku Odbudowy i Rozwoju (EBOiR). Wzrost wzajemnych powiązań handlowych oraz perspektywa otrzymania znacznych środków pomocowych sprawiła, że powodzenie procesu transformacji systemowej i gospodarczej zostało uzależnione od bliskiej współpracy z państwami WE: Bilateralne umowy handlowe, jakie Wspólnota podpisywata z poszczególnymi państwami Europy Środkowo-Wschodniej, miaty dla niej przede wszystkim znaczenie polityczne, natomiast państwa EŚW - w tym Polska - pragnęty uzyskać wymierne korzyści gospodarcze. Taki stan rzeczy był niewątpliwie spowodowany zapóźnieniem cywilizacyjnym, jakie państwa byłego bloku wschodniego wyniosły po okresie socjalizmu oraz gospodarce centralnie planowanej. Przypadek Polski okazał się szczególnie niepokojący, ze względu na katastrofalną sytuację gospodarczą przełomu lat 1989-1990 oraz zastosowanie terapii szokowej przy dochodzeniu do stabilizacji makroekonomicznej ${ }^{10}$. Pomyślne przeprowadzenie reform wolnorynkowych zależało $\mathrm{w}$ dużej mierze od stopnia pomocy zagranicznej oraz podpisania preferencyjnych umów handlowych. Zacieśnienie współpracy z krajami EWG, stanowiącymi największy rynek zbytu na kontynencie oraz główne źródło pomocy finansowej, stało się priorytetem polskiej polityki zagranicznej.

Niezależnie od względów ekonomicznych, bliższa współpraca z państwami Europy Zachodniej dawała nadzieję na zapewnienie bezpieczeństwa w pozimnowojennym ładzie politycznym oraz uniezależnienie się od wpływów postsowieckich. W założeniach polskiego rządu miała stanowić [...] dodatkowa, obok cztonkostwa $w$ NATO, gwarancje bezpieczeństwa $i$ utrwalenia $w$ naszym kraju demokratycznego modelu ustrojowego ${ }^{11}$. Wyrazem tych oczekiwań było złożenie wniosku o rozpoczęcie rozmów w sprawie umowy stowarzyszeniowej pomiędzy Polską a Wspólnotami

EWG-Polska. Umowa w sprawie handlu oraz wspótpracy handlowej i gospodarczej, Dz. U. 1990, nr 38, poz. 214.

8 W latach 1989-2000 Polsce przyznano z programu PHARE łączną kwotę 2,53 mld euro, z czego zakontraktowano $84 \%$ przyznanych środków. Por. Partnership for the accession of Poland, EUROPA - EU website, 19 XI 2004, [online] http://europa.eu/legislation_summaries/enlargement/2004_ and_2007_enlargement/e40106_en.htm, 5 IX 2012.

9 A.Z. Nowak, D. Milczarek, Proces integracji Polski z Unia Europejska, [w:] Europeistyka w zarysie, red. tychże, Warszawa 2006, s. 416.

10 Realne tempo wzrostu PKB wyniosło na początku 1990 r. -11,6\%, średnioroczna stopa inflacji $585,8 \%$, spadek dochodów realnych na 1 mieszkańca wyniósł 27,6\%. Por. Gospodarka Polski w latach 1990-2000, Ministerstwo Gospodarki, Warszawa 2001.

11 Raportwsprawiekorzyści ikosztów integracji Rzeczpospolitej Polskiejz Unią Europejską, Rada Ministrów, Warszawa 2000, s. 8. 
Europejskimi, które zakończyły się podpisaniem tzw. Układu Europejskiego w grudniu $1991 \mathrm{r}^{12}$ Stowarzyszenie zapewniło ramy dialogu politycznego, stworzyło podstawy udzielania Polsce pomocy finansowej i technicznej oraz umożliwiło dalszy rozwój stosunków gospodarczych pomiędzy stronami. Jego przyjęcie można uznać za symboliczne sfinalizowanie pierwszego etapu na drodze do otwarcia negocjacji akcesyjnych, choć sam Układ nie stanowił gwarancji pełnego członkostwa we Wspólnotach w przyszłości.

Kolejnym krokiem w kierunku zacieśniania współpracy z państwami WE było wdrożenie Układu Europejskiego w życie. Pomimo że do jego ratyfikacji doszło dopiero w lutym 1994 r., postanowienia dotyczące liberalizacji przepływu towarów, a w dalszej kolejności również usług, osób i kapitału, zaczęły obowiązywać w marcu 1992 r. Pozwoliło to na zintensyfikowanie wzajemnej wymiany handlowej oraz wywołało przymus modernizacyjny dla polskich przedsiębiorstw spowodowany presją konkurencyjną ze strony zagranicznych firm. Strona polska, jako partner słabszy gospodarczo, wynegocjowała w ramach Układu preferencyjne klauzule ochronne na wybrane artykuły przemysłowe oraz asymetryczną redukcję ceł pozostałych towarów. Niezależnie od tych zabiegów, bilans handlowy pomiędzy stronami okazał się niekorzystny dla Polski, a kraje dotychczasowej EWG umocniły się na pozycji głównego partnera handlowego $^{13}$. Stopniowej liberalizacji handlu towarzyszyły również przewidziane w Układzie działania dostosowawcze w sferze legislacyjnej. Na ich podstawie polski rząd przygotował program harmonizacji krajowego systemu prawnego z dorobkiem wspólnotowym (acquis communautaire $)^{14}$. Procedury wypracowane na potrzeby wdrażania w życie umowy stowarzyszeniowej okazały się kluczowym narzędziem późniejszych przygotowań Polski do członkostwa w UE. Przełomowego znaczenia nabrało ustanowienie ram dialogu politycznego w postaci regularnych posiedzeń organów Stowarzyszenia ${ }^{15}$. Ich działalność nie ograniczała się do nadzorowania bieżącej realizacji założeń Układu, ale stanowiła forum do dyskusji nad możliwościami przyszłego rozszerzenia WE o kraje stowarzyszone. W tej roli wyróżniały się obrady Parlamentarnej Komisji Wspólnej (Joint Parliamentary Committee), która grupowała przedstawicieli Sejmu i Senatu RP oraz deputowanych Parlamentu Europejskiego.

Wejście w życie Układu Europejskiego stanowiło potwierdzenie dążenia obu stron do dalszej integracji politycznej i gospodarczej, choć w przeważającym stopniu spro-

12 Uktad Europejski ustanawiajacy stowarzyszenie między Rzeczpospolita Polska, z jednej strony, a Wspólnotami Europejskimi i ich panstwami cztonkowskimi, z drugiej strony, sporządzony w Brukseli dnia 16 grudnia 1991 r., Dz. U. 1994, nr 11, poz. 38.

13 Państwa członkowskie WE stały się głównym partnerem handlowym Polski już w 1990 r. Por. Polska i Unia Europejska. Stan obecny i wyzwania na przysztość, red. U. Płowiec, Warszawa 2000, s. 327.

14 Por. Uchwata Sejmu RP z dnia 4 lipca 1992 r. w sprawie realizacji Uktadu Europejskiego ustanawiajacego stowarzyszenie między Rzeczpospolitą Polską a Wspólnotami Europejskimi i ich państwami cztonkowskimi, Monitor Polski 1992, nr 23, poz. 165.

15 Głównym organem decyzyjnym została wyznaczona Rada Stowarzyszenia, składająca się z członków polskiego rządu, Rady WE oraz Komisji WE. Organem pomocniczym ustanowiono Parlamentarny Komitet Stowarzyszenia, składający się z członków Parlamentu RP z jednej strony oraz Parlamentu Europejskiego z drugiej. 
wadzała się ona do działań przystosowawczych ze strony polskiej. Wyrazem otwartości ze strony wspólnotowej było natomiast przyjęcie Traktatu o Unii Europejskiej (TUE), który przewidywał w art. 49 możliwość rozszerzenia nowo powstałej Unii o każde państwo europejskie respektujące jej podstawowe wartości, takie jak poszanowanie godności osoby ludzkiej, wolności, demokracji, równości, państwa prawnego czy przestrzeganie praw człowieka ${ }^{16}$. W ślad za wpisaniem do treści Traktatu preliminarnych warunków członkostwa poszło sformułowanie kryteriów politycznych oraz ekonomicznych, przyjętych na szczycie Rady Europejskiej w Kopenhadze 21-22 czerwca 1993 r. Tzw. kryteria kopenhaskie wyznaczały kierunek starań dla krajów EŚW zabiegających o wstąpienie do Unii. Dawały tym samym podstawy do złożenia oficjalnego wniosku o członkostwo. W przypadku Polski wniosek taki został notyfikowany Radzie Unii Europejskiej w kwietniu 1994 r., stanowiąc jednocześnie zapewnienie rządu polskiego o spełnieniu kryteriów kopenhaskich ${ }^{17}$.

Przyjęcie wniosku przez Radę UE, a następnie Radę Europejską w czerwcu 1994 r., rozpoczęło kolejny etap na drodze do integracji Polski z Unią Europejską, tzw. etap właściwej procedury akcesyjnej ${ }^{18}$. W pierwszej kolejności polska kandydatura została skierowana do Komisji Europejskiej, mającej przygotować opinię (avis) na temat stopnia realizacji kryteriów kopenhaskich oraz programów dostosowawczych. W trakcie procesu weryfikacji wniosku o członkostwo Komisja opracowała dalsze wytyczne dla krajów stowarzyszonych w postaci tzw. Białej Księgi ${ }^{19}$. Wyznaczała ona sugerowaną kolejność i tempo wdrażania głównych aktów prawnych na drodze do integracji z rynkiem wewnętrznym UE. Stała się jednocześnie przewodnikiem po legislacji wspólnotowej dla krajów EŚW, które w perspektywie akcesji zostały zobowiązane do przyjęcia całości dorobku prawnego Unii. Ocena działań dostosowawczych Polski, koordynowanych przez Komitet Integracji Europejskiej (KIE), została wyrażona przez Komisję dopiero w lipcu 1997 r. ${ }^{20}$ Tak długi czas oczekiwania był spowodowany potrzebą zweryfikowania stopnia realizacji programów przygotowawczych, reform gospodarczych, politycznych i spolecznych po stronie polskiej, jak również stworzenia odpowiednich warunków do rozszerzenia w strukturze unijnej. Pozytywna opinia Komisji, wraz z zaleceniem rozpoczęcia negocjacji z Polską, pozwoliła na przyjęcie oficjalnego stanowiska państw członkowskich UE o gotowości do rozpoczęcia rozmów dwustronnych. Decyzja podjęta podczas szczytu w Luksemburgu w grudniu 1997 r. sprawiła, że Polska znalazła się w gronie pierwszych państw kandydujących z regionu Europy Środkowo-Wschodniej, łącznie

16 Podstawowe wartości Unii zostały wymienione w art. 2 TUE. Por. Wersja skonsolidowana Traktatu o Unii..., art. 2.

17 Do wniosku o członkostwo dołączone było memorandum o spełnieniu kryteriów ustalonych przez Radę Europejską w Kopenhadze oraz gotowości Polski do rozpoczęcia negocjacji akcesyjnych.

18 Zob. Proces integracji Polski z Unia Europejska..., s. 420.

19 White Paper: Preparation of the Associated Countries of Central and Eastern Europe for Integration into the Internal Market of the Union, $\operatorname{COM(95)~163,~} 1995$.

20 Agenda 2000. Opinia Komisji Europejskiej o wniosku Polski o cztonkostwo w Unii Europejskiej, „Monitor Integracji Europejskiej" (wydanie specjalne) 1997, s. 102. 
z Republiką Czeską i Węgrami²1 . Na stanowisko Pełnomocnika Rządu ds. Negocjacji o członkostwo RP w Unii Europejskiej oraz jako główny negocjator został powołany Jan Kułakowski.

\subsection{Przebieg negocjacji akcesyjnych}

Przechodząc do omówienia przebiegu negocjacji, należy zauważyć, że już od samego początku były one prowadzone w warunkach politycznej i gospodarczej asymetrii pomiędzy Unią Europejską a poszczególnymi państwami kandydującymi. Przyjęcie zasady, że każda kandydatura będzie rozpatrywana przez Unię z osobna, jeszcze bardziej osłabiło pozycję wyjściową krajów ÉSW, przechodzących trudny okres transformacji ustrojowej i gospodarczej. Nierówność partnerów podchodzących do negocjacji dobrze ilustruje przypadek Polski, której gospodarka oraz perspektywy modernizacyjne zostały w znacznym stopniu uzależnione od dostępu do europejskich rynków zbytu oraz pomocy finansowej. Jednocześnie rynek krajowy zostały wystawiony na presję konkurencyjną ze strony zagranicznych przedsiębiorstw, której w wielu sektorach nie był w stanie sprostać.

W tych warunkach priorytetem strony polskiej stało się uzyskanie szybkiego dostępu do korzyści ekonomicznych i politycznych wynikających z pełnego członkostwa, przy jednoczesnym wynegocjowaniu derogacji oraz tzw. okresów przejściowych w obszarach, które nie były przygotowane na działanie sił konkurencyjnych w ramach rynku wewnętrznego. Podnoszonym przez Polskę argumentem za wprowadzeniem okresów przejściowych był niski poziom rozwoju gospodarczego oraz PKB w stosunku do średniej unijnej. Innym uzasadnieniem stała się potrzeba ponoszenia wysokich kosztów restrukturyzacji gospodarki i przystosowywania jej do unijnych standardów ${ }^{22}$. Strona polska dążyła tym samym do zagwarantowania jej pozycji beneficjenta netto, tzn. państwa, które więcej środków otrzymuje z unijnego budżetu, niż do niego wnosi. W interesie państw UE było natomiast uzyskanie okresów przejściowych w dochodzeniu Polski do pełnych praw członkowskich, które przyznane jednorazowo mogłyby nadwyrężyć wspólnotowy budżet oraz równowagę i stabilność rynku wewnętrznego. Nie należy zapominać, że Polska stanowiła największą gospodarkę wśród krajów kandydujących, porównywalną rozmiarami z rynkami dużych krajów członkowskich. Jej potrzeby finansowe oraz możliwości produkcyjne budziły uzasadnione obawy państw zachodnich o utratę stabilizacji ekonomicznej. Perspektywa akcesji 38-milionowego kraju oznaczała również zmianę układu sił politycznych w Unii, szczególnie po przyjęciu ustaleń wynikających z Traktatu nicejskiego ${ }^{23}$.

21 Do grona państw zaproszonych do rozpoczęcia negocjacji (tzw. Grupy Luksemburskiej) zaliczały się również Estonia, Słowenia i Cypr.

22 Zob. J.M. Fiszer, Negocjacje i perspektywy cztonkostwa Polski w Unii Europejskiej, [w:] tenże, Unia Europejska a Polska. Dziś i jutro, Toruń 2004, s. 104.

23 W ramach Traktatu nicejskiego przewidziano reformę instytucjonalną UE, przygotowując jej organy na przyjęcie nowych państw. Podział głosów w PE i Radzie UE przeprowadzono z uwzględnieniem czynnika demograficznego, faworyzującym duże kraje. Por. Traktat z Nicei, Dz. U. UE C 80 z 10 III 2001. 
Przystąpienie do właściwych negocjacji zostało poprzedzone przeprowadzeniem procedury screeningu. W jego ramach Komisja przedstawiła krajom kandydującym dorobek prawny wspólnoty podzielony na 31 rozdziałów tematycznych. W następnej kolejności poszczególne państwa zostały zobowiązane do przeglądu prawa krajowego pod kątem jego zgodności z acquis communautaire. Zidentyfikowane nieścisłości miały się przyczynić do wyznaczenia problemowych kwestii w wybranych obszarach oraz pozwolić na wypracowanie stanowisk negocjacyjnych. Zamknięcie procedury screeningu w najważniejszych dziedzinach pozwoliło na rozpoczęcie negocjacji merytorycznych w ich obrębie, co nastąpiło ostatecznie w listopadzie $1998 \mathrm{r}$. Do końca następnego roku strona polska złożyła stanowiska we wszystkich przewidzianych obszarach, przyjmując za cel sfinalizowanie negocjacji w ciągu 2 lat i przystąpienie do struktur unijnych w 2004 r. Największe trudności sprawiły rozmowy w obszarach dotyczących finansowego wymiaru członkostwa, tj.: „Finanse i budżet”, „Rolnictwo”, „Polityka regionalna i koordynacja instrumentów strukturalnych”, „Polityka konkurencji” oraz „Podatki”. Spore kontrowersje wywołały również negocjacje w kwestii swobodnego przepływu osób, w tym podejmowania zatrudnienia za granicą. Ze względu na obawy państw członkowskich przed „zalaniem” ich rynków pracy tanią siłą roboczą z krajów EŚW, Unia zażądała przyjęcia okresów przejściowych w tym obszarze, pozostawiając decyzję o ich wprowadzeniu w kompetencji swoich członków. Znaczny wpływ na przebieg negocjacji miały również obawy polskiego społeczeństwa spowodowane perspektywą wykupu ziemi przez obcokrajowców. W ich efekcie Polska wynegocjowała najdłuższy spośród wszystkich państw kandydujących okres przejściowy w tym zakresie (aż dwanaście lat $)^{24}$. Nastroje społeczne odegrały dużą rolę w procesie negocjacji. Przedstawienie poszczególnych obszarów problemowych pozwoli na pełniejsze zrozumienie ich natury, a także aspiracji obu stron.

\subsubsection{Finanse i budżet}

Rokowania w obszarze „Finanse i budżet” rozpoczęły się w maju 2000 r. Ich przedmiotem było ustalenie sposobu wpłacania przez Polskę środków do budżetu unijnego oraz zasad korzystania z przynależnych dopłat wspólnotowych. Priorytetem dla zachowania stabilności makroekonomicznej oraz podtrzymania rozwoju gospodarczego kraju stało się uzyskanie pozycji beneficjenta netto już od pierwszego roku członko$s{ }^{25} a^{25}$. Oczekiwania strony polskiej zostały uwzględnione poprzez przyznanie jej dodatkowych środków finansowych na lata 2004-2006 w wysokości 1,4 mld euro, jednak mieszczących się w granicach wydatków przewidzianych w perspektywie budżetowej Unii na okres 2000-2006. Wynegocjowana kwota miała pozwolić na stopniowe przeprowadzenie adaptacji struktury finansów publicznych do warunków wspólnotowych oraz zachowanie płynności budżetowej po akcesji. Dodatkowe środki zostały również

\footnotetext{
24 Raport na temat rezultatów negocjacji o cztonkostwo Rzeczypospolitej Polskiej w Unii Europejskiej, Rada Ministrów, Warszawa 2012, s. 13.

25

Tamże, s. 43.
} 
przydzielone na przystosowanie granicy zewnętrznej do wymogów systemu Schengen. Otrzymanie gwarancji finansowych pozwoliło na uspokojenie niepokojów społecznych związanych z trudną sytuacją gospodarczą w kraju. Przyczyniło się tym samym do podtrzymania opinii o pozytywnym wpływie członkostwa w UE na stan polskiej gospodarki oraz zmniejszenie bezrobocia ${ }^{26}$. Rozmowy nad kwestiami finansowymi oraz budżetowymi trwały do końca przewidzianego okresu negocjacyjnego i zakończyły się ostatecznie w grudniu 2002 r. podczas szczytu Rady Europejskiej w Kopenhadze, co potwierdziło ich duże znaczenie dla negocjatorów, w szczególności dla strony polskiej jako partnera słabszego gospodarczo.

\subsubsection{Rolnictwo}

Kolejnym problemowym obszarem okazało się „Rolnictwo”, w związku z brakiem porozumienia w kwestii przyznawania dopłat bezpośrednich dla rolników. Strona polska domagała się objęcia krajowego rolnictwa pełnym zakresem działania Wspólnej Polityki Rolnej (WPR), w ramach którego prawodawstwo unijne przewidywało wsparcie cenowe, dochodowe i strukturalne, jak również wspomniany system płatności bezpośrednich ${ }^{27}$. Wśród problemów negocjacyjnych znalazło się ponadto ustalenie limitów produkcji poszczególnych towarów. Ich wysokość miała decydujący wpływ na stopień wykorzystania możliwości produkcyjnych polskiego rolnictwa na rynku wewnętrznym UE. W stanowisku wyjściowym Unia nie przewidywała przyznania dopłat bezpośrednich do rolnictwa dla nowych krajów członkowskich, zgodnie z założeniami Agendy $2000^{28}$. W celu ochrony rynku wewnętrznego postulowała ustanowienie znacznych limitów produkcji na polskie produkty żywnościowe, m.in. mleko, cukier czy skrobię ziemniaczaną. Rozmowy zostały dodatkowo utrudnione ze względu na wewnętrzną debatę w UE nad kształtem reformy WPR. Część państw członkowskich opowiadała się za stopniową likwidacją systemu dopłat bezpośrednich, uznając go za nieefektywny. Unijni negocjatorzy nie byli tym samym zdolni do zajęcia jednoznacznego stanowiska w kwestii finansowania polskiego rolnictwa. Ostatecznie, zgodnie z propozycją Komisji Europejskiej, uzgodniono stopniowy wzrost poziomu dopłat bezpośrednich dla nowych krajów członkowskich, poczynając od poziomu $25 \%$ pelnego dofinansowania w 2004 r. ${ }^{29}$ Stronie polskiej udało się dodatkowo wynegocjować możliwość przesunięcia części środków z funduszów na rozwój wsi i obszarów wiejskich do puli dopłat bezpośrednich. Takie rozwiązania okazały się kluczowe dla Polski, jako kraju dysponującego największym rynkiem rolnym wśród państw kandydujących. Dochodzenie do pełnego poziomu dofinansowania miało trwać przez 10 lat od

26 Opinie o integracji Polski z Unia Europejska. Komunikat z badań, Centrum Badań Opinii Społecznej, Warszawa 2002, s. 8-10.

27 Raport na temat rezultatów negocjacji..., s. 16-17.

28 Agenda 2000. Unia Europejska rozszerzona i silniejsza, „Monitor Integracji Europejskiej” (wydanie specjalne) 1997, s. 31 .

29 Raport na temat rezultatów negocjacji..., s. 17. 
rozszerzenia, co oznacza, że polscy rolnicy do dziś nie otrzymują pełni przysługujących im subsydiów. Dzięki podwyższeniu zaproponowanych przez UE kwot produkcyjnych polskie towary okazały się wysoko konkurencyjne cenowo po zlikwidowaniu ograniczeń w handlu żywnością ${ }^{30}$. Pomyślne dla Polski wyniki negocjacji w obszarze „Rolnictwo” zostały zweryfikowane systematyczną poprawą nastawienia środowisk rolniczych do kwestii członkostwa w UE. Uruchomienie płatności bezpośrednich oraz dobre wyniki sektora rolnego po akcesji sprawiły, że poparcie rolników dla członkostwa wzrosło z $20 \%$ w styczniu 2004 r. do $60 \%$ w lutym 2005 r. ${ }^{31}$

\subsubsection{Polityka konkurencji}

Trudności w negocjacjach, które wzbudziły duże zainteresowanie społeczne w Polsce, dotyczyły również obszaru „Polityka konkurencji”. Różnice w stanowiskach negocjacyjnych sprowadzały się do dwóch zasadniczych kwestii: warunków funkcjonowania Specjalnych Stref Ekonomicznych (SSE) oraz sposobu restrukturyzacji polskiego hutnictwa. Strona unijna domagała się całkowitego dostosowania zasad pomocy publicznej dla przedsiębiorstw do reguł konkurencji obowiązujących w ramach jednolitego rynku. Zgodnie z postanowieniami traktatowymi ingerencja instytucji państwowych na wolnym rynku jest, co do zasady, zabroniona ${ }^{32}$. Niezależnie od tego Polska postulowała podtrzymanie ulg podatkowych oraz innych przywilejów budżetowych dla przedsiębiorstw, które rozpoczęły swoją działalność na obszarze SSE przed objęciem zasad ich funkcjonowania regulacjami wspólnotowymi ${ }^{33}$. Na drodze osiągniętego kompromisu pułap pomocy publicznej dla dużych przedsiębiorstw spełniających powyższy warunek został ograniczony do 75\% i 50\% kosztów inwestycji (w zależności od daty rozpoczęcia działalności). Małe i średnie przedsiębiorstwa uzyskały z kolei okresy przejściowe w warunkach korzystania z pomocy, odpowiednio do 2011 i 2010 r. Takie rozwiązania sprawiły, że Polska pozostała atrakcyjnym miejscem do rozwijania działalności gospodarczej.

Bardziej restrykcyjne ograniczenia zostały nałożone na sektor hutnictwa. Ceną za utrzymanie znacznego poziomu pomocy publicznej do $2003 \mathrm{r}$. było przeprowadzenie gruntownej restrukturyzacji polskich hut, w tym ograniczenia ich mocy produkcyjnej oraz redukcji zatrudnienia. Strona polska zobowiązała się do osiągnięcia rentowności sektora najpóźniej do 2006 r. Jednoznaczne stanowisko negocjacyjne Komisji w kwestii restrukturyzacji wynikało z obawy przed zakłóceniem konkurencji w ramach jednolitego rynku. Potencjał produkcyjny polskiego hutnictwa odpowiadał

30 Dodatnie saldo w wymianie handlowej produktami rolno-spożywczymi z państwami UE-15 w 2005 r. wyniosło 1,6 mld euro. Por. Polskie Rolnictwo - Dwa latapo akcesji do UE, Fundacja Programów Pomocy dla Rolnictwa, Warszawa 2006, s. 22.

31 Według badań na zlecenie Urzędu Komitetu Integracji Europejskiej. Tamże, s. 22.

32 Por. Wersja skonsolidowana Traktatu o funkcjonowaniu Unii Europejskiej, Dz. U. UE C 83 z 30 III 2010, art. 107, ust. 1 (dawny art. 87 Traktatu ustanawiającego Wspólnotę Europejską).

33 Objęcie zasad funkcjonowania Specjalnych Stref Ekonomicznych przepisami prawa wspólnotowego (w tym regułami unijnej polityki konkurencji) nastąpiło 1 I $2001 \mathrm{r}$. 
bowiem zdolnościom wytwórczym wszystkich państw członkowskich razem wziętych $^{34}$. Koszty społeczne związane z ograniczeniem produkcji, wywołane redukcją zatrudnienia o 22,4\% w latach 2003-2006, odbiły się negatywnie na ocenie sposobu restrukturyzacji polskiego hutnictwa ${ }^{35}$. W oczach opinii społecznej wynik negocjacji w obszarze „Polityka konkurencji” był tym samym niekorzystny dla Polski; wzmocniło to przekonanie o negatywnym wpływie integracji z UE na kondycję państwowych przedsiębiorstw ${ }^{36}$.

\subsection{Zamknięcie i ocena negocjacji}

Etap negocjacji merytorycznych trwał do 13 grudnia 2002 r. i został ostatecznie zamknięty na posiedzeniu Rady Europejskiej w Kopenhadze. Rozmowy w najtrudniejszych obszarach zostały sfinalizowane w ostatniej rundzie negocjacyjnej pomiędzy 25 października a 12 grudnia. Brak porozumienia groził przesunięciem przewidywanej daty akcesji do 2005 r. Presja konkurencyjna ze strony innych państw kandydujących oraz perspektywa niewykorzystanej szansy rozwojowej skłaniały do przyjęcia kompromisów oraz zakończenia rozmów w terminie. W efekcie stronie polskiej udało się uzyskać okresy przejściowe w takich obszarach, jak: „Polityka konkurencji”, „Polityka transportowa”, „Polityka społeczna i zatrudnienie”, „Swoboda świadczenia usług”, „Swobodny przepływ kapitału”, „Energia”, „Środowisko” oraz „Podatki”. Pod tym względem Polska uzyskała najlepsze warunki pośród wszystkich państw kandydujących, przy jednoczesnym zachowaniu całości praw wynikających z członkostwa. Pozwoliło to na uniknięcie tzw. efektów szokowych związanych z liberalizacją gospodarki oraz zwiększoną konkurencją w ramach jednolitego rynku ${ }^{37}$. Pomyślne rezultaty negocjacji we wrażliwych dla Polski sektorach zostały jednak przysłonięte ograniczeniami w dochodzeniu do pełni praw członkowskich, szczególnie w kwestii dopłat bezpośrednich dla rolników oraz swobodnego przepływu osób. Wywarły one negatywny wpływ na ogólną ocenę warunków przyszłego członkostwa.

Nie należy przy tym zapominać, że strona polska zajmowała słabszą pozycję w trakcie procesu negocjacyjnego, zarówno pod względem gospodarczym, jak i politycznym. Asymetria w relacjach z Unią, która istniała już od pierwszych etapów integracji, wymagała podjęcia pewnych wysiłków dostosowawczych. Strona unijna dążyła bowiem do maksymalizacji wymogów związanych z przyjęciem prawa wspólnotowego. Niezależnie od zajmowania słabszej pozycji, polskim negocjatorom udało się osiągnąć równowagę pomiędzy przyjęciem okresów przejściowych a uzyskaniem pełni praw członkowskich. W opinii Danuty Hübner, przewodniczącej Polskiego Zespołu Negocjacyjnego, cało-

34 J.M. Fiszer, Negocjacje i perspektywy..., s. 112.

35 W. Szulc, B. Garbarz, J. Paduch, Przebieg i wyniki restrukturyzacji przemystu stalowego w Polsce, „Prace Instytutu Metalurgii Żelaza" 2011, nr 4, [online] http://www.imz.pl/Periodyk/2011/11-4-4-Szulc. pdf, 5 IX 2012.

36 Opinie o integracji Polski z Unią Europejska..., s. 8.

37 Zob. Raport na temat rezultatów negocjacji..., s. 47. 
ściowy wynik negocjacji można uznać za korzystny dla Polski: Osiagnięte zostaty najważniejsze cele sformutowane $w 1998 \mathrm{r}$. jako stanowiska negocjacyjne rządu polskiego ${ }^{38}$. Pomimo zmiennych nastrojów społecznych, wyrazem końcowej akceptacji warunków polskiego członkostwa w strukturach unijnych okazał się wynik referendum akcesyjnego, przeprowadzonego w dniach 7-8 czerwca 2003 r. Za przystąpieniem Polski do Unii Europejskiej opowiedziało się 77,45\% głosujących, przy czym frekwencja wyborcza wyniosła $58,85 \%^{39}$. Pomyślny wynik referendum pozwolił na ratyfikowanie Traktatu akcesyjnego, wypracowanego w efekcie procedury negocjacyjnej. Na jego mocy Polska stała się aktywnym obserwatorem w instytucjach unijnych, a od 1 maja 2004 r. pełnoprawnym członkiem Unii. Wraz z przystąpieniem do UE pozycja międzynarodowa kraju, zarówno w wymiarze politycznym, jak i gospodarczym, znacznie się umocniła. Polska zyskała możliwość uczestnictwa we wspólnej polityce zagranicznej i bezpieczeństwa Unii oraz dostęp do największego rynku wewnętrznego na świecie. Stopień osiąganych z tego tytułu korzyści został jednak uzależniony od możliwości adaptacyjnych nowych państw członkowskich. Proces dostosowywania się do unijnych standardów w wielu dziedzinach trwa w Polsce do chwili obecnej. Prawdziwym egzaminem dojrzałości dla polskiego członkostwa okazało się objęcie prezydencji w Radzie Unii Europejskiej $\mathrm{w}$ drugiej połowie $2011 \mathrm{r}$.

\section{PRZYSZŁOŚĆ POLSKI W UE}

Stając się pełnoprawnym członkiem Unii, Polska zyskała możliwość kształtowania unijnej agendy oraz współuczestnictwa w debacie nad przyszłym modelem politycznym, gospodarczym czy społecznym wspólnoty. Aktywność strony polskiej na forum unijnym została zintensyfikowana w ramach objęcia przewodnictwa w Radzie UE w drugiej połowie 2011 r. Sprawowanie półrocznej prezydencji było jednocześnie okazją do sformułowania i realizacji priorytetów, które odzwierciedlają polskie dążenia na arenie europejskiej. W tym kontekście prezydencję rozumieć należy jako [...] sztukę i zdolność wyrażania wtasnych zamierzeń poprzez wykreowany wspólny program dla catej Unii Europejskiej, [...] umiejętność ukrycia celu wtasnego w zbiorze aktywności wspólnych UE, a tym samym zdolność do unikania ekspozycji partykularnych interesów kraju prezydencji $i^{40}$. Wśsód głównych celów polskiego przewodnictwa znalazły się m.in. kwestie: Partnerstwa Wschodniego i rozszerzenia UE (w ramach priorytetu Otwarta Europa), bezpieczeństwa energetycznego oraz zdolności obronnych (Bezpieczna Europa), wzmocnienia rynku wewnętrznego i negocjacji Wieloletnich Ram Finansowych 2014-

38 Polska - Unia Europejska, Ambasada Rzeczypospolitej Polskiej w Caracas, [online] http://www.caracas.polemb.net/?document=49, 7 IX 2012.

39 Obwieszczenie Państwowej Komisji Wyborczej z dnia 9 czerwca 2003 r. o wyniku ogólnokrajowego referendum w sprawie wyrażenia zgody na ratyfikacje Traktatu dotyczacego przystapienia Rzeczypospolitej Polskiej do Unii Europejskiej, Dz. U. 2003, nr 103, poz. 953.

40 Z. Czachór, Prezydencja w Unii Europejskiej i jej priorytety, [w:] Priorytety prezydencji Polski w Radzie Unii Europejskiej. Analiza politologiczna, red. Z. Czachór, T.R. Szymczyński, Warszawa 2011, s. 27. 
-2020 (Integracja europejska jako źródło wzrostu) ${ }^{41}$. Tak sformułowane priorytety można potraktować jako emanację pożądanego przez stronę polską kierunku rozwoju polityki unijnej. Wskazują bowiem na obszary strategiczne z perspektywy polskiej racji stanu. Ich omówienie pozwoli odpowiedzieć na pytanie, w jakiej Unii Europejskiej Polska chce uczestniczyć w przyszłości, a zarazem w jakiej roli postrzega samą siebie w unijnych strukturach.

\subsection{Priorytety polskiej prezydencji}

\subsubsection{Integracja europejska jako źródło wzrostu}

Okres sprawowania przewodnictwa Polski w Radzie UE przypadł na trudną sytuację społeczno-gospodarczą spowodowaną konsekwencjami światowego kryzysu finansowego, który w Europie szczególnie boleśnie doświadczył gospodarki południowych krajów unii walutowej ${ }^{42}$. Polska przyjęła w obliczu kryzysu w strefie euro stanowisko prointegracyjne, postulując zwiększenie koordynacji polityk gospodarczych państw członkowskich. W trakcie polskiej prezydencji doszło m.in. do przyjęcia tzw. „sześciopaku”, czyli zestawu sześciu aktów prawnych wzmacniających zarządzanie gospodarcze w UE, a także ustanawiających mechanizmy nadzoru nad polityką budżetową państw strefy euro ${ }^{43}$. W interesie strony polskiej było włączenie w działania koordynacyjne wszystkich państw członkowskich zobligowanych do przyjęcia wspólnej waluty w przyszłości. Celem tych starań było uniknięcie podziału na kraje strefy euro, jako awangardę tworzącą nowe ramy integracji gospodarczej, oraz pozostałe państwa, znajdujące się poza unią walutową i skazane na działania dostosowawcze. Starania podjęte w ramach realizacji obszaru priorytetowego „Integracja europejska jako źródło wzrostu" dotyczyły ponadto pogłębiania koordynacji w ramach rynku wewnętrznego. Dobrym przykładem może być sfinalizowanie dyskusji nad systemem jednolitej ochrony patentowej w Unii oraz zainicjowanie rozmów na temat ułatwień przy zawieraniu transgranicznych umów sprzedaży online $e^{44}$.

Podczas trwania polskiej prezydencji zapoczątkowano również negocjacje nad Wieloletnimi Ramami Finansowymi (WRF) na lata 2014-2020. Stanowisko reprezentowane przez Polskę zakładało potraktowanie przyszłego budżetu Unii w kategorii narzędzia inwestycyjnego, mającego pobudzić wzrost gospodarczy w Europie. Podtrzymanie

41 Por. Program polskiej prezydencji w Radzie Unii Europejskiej, Ministerstwo Spraw Zagranicznych, Warszawa 2011, [online] http://pl2011.eu/sites/default/files/users/shared/o_prezydencja/program_polskiej_prezydencji_w_radzie_ue.pdf, 7 IX 2012.

42 Początek kryzysu finansowego i gospodarczego w Europie datuje się na drugą połowę $2007 \mathrm{r}$. Por. J. Zombirt, Unia Europejska wobec kryzysu finansowego i gospodarczego, [w:] tejże, Mechanizmy rynku wewnętrznego Unii Europejskiej, Warszawa 2011, s. 571-577.

43 Por. Przewodnictwo Polski w Radzie Unii Europejskiej. Raport końcowy z przygotowania i sprawowania prezydencji, Ministerstwo Spraw Zagranicznych, Warszawa 2002, s.166-167, [online] http://pl2011. eu/sites/default/files/users/user43/raport_koncowy__rm_17.04.2012.pdf, 12 IX 2012.

44 Tamże, s. 165 i 188. 
dotychczasowych wydatków na politykę rolną i politykę spójności, pozwalających niwelować różnice w rozwoju społeczno-gospodarczym wewnątrz Unii, leży w gestii wszystkich państw z regionu EŚW. W przeświadczeniu krajów o wysokim poziomie rozwoju, a więc płatników netto do unijnego budżetu, więcej środków niż dotychczas powinno zostać przeznaczonych na pobudzanie wzrostu gospodarczego bezpośrednio na ich terytorium. Zadaniem Polski podczas okresu sprawowania prezydencji, jak również w toku dalszych negocjacji nad przyszłą perspektywą budżetową UE, będzie więc przekonanie „starych członków" o słuszności zwiększania wydatków na politykę spójności jako sposobu przezwyciężenia kryzysu w całej Unii. W tym celu strona polska może posiłkować się wyliczeniami wysokiej stopy zwrotu pomocy przekazywanej ze strony państw UE-15, czego przykładem było wystąpienie ministra Radosława Sikorskiego w Berlinie ${ }^{45}$. W tym kontekście należy również odczytywać federalistyczną wizję przyszłej Unii Europejskiej zaprezentowaną przez szefa polskiej dyplomacji. Wzmocnienie struktur unijnych, a w szczególności zwiększenie wydatków ze wspólnotowego budżetu, leży w żywotnym interesie Polski jako ich głównego beneficjenta. Celem przewodnim polskiego rządu powinno być zapobieganie groźbie fragmentaryzacji Unii oraz podtrzymanie jej solidarnościowego charakteru. Rola Polski nie powinna się jednak ograniczać do działań prewencyjnych oraz stania na straży przestrzegania traktatów. Jej działania powinny inspirować do wzmacniania integracji gospodarczej i politycznej wewnątrz wspólnoty, dbając jednocześnie o równą pozycję wszystkich jej członków, w szczególności krajów EŚW. Realizacja założeń przewidzianych w ramach priorytetu „Integracja europejska jako źródło wzrostu”, a zatem wzmacnianie rynku wewnętrznego oraz polityki spójności w przyszłej perspektywie finansowej UE, wydaje się potwierdzeniem tych ambicji.

\subsubsection{Europa Otwarta}

Podobne wnioski można wyciągnąć z analizy dwóch pozostałych obszarów priorytetowych realizowanych w ramach polskiej prezydencji, tj. „Europa Otwarta” oraz „Europa Bezpieczna”. Ich omówienie zostanie przeprowadzone kolejno po sobie, ponieważ mają one wiele wspólnego - odwołują się do wzmocnienia poziomu bezpieczeństwa i dobrobytu w najbliższym sąsiedztwie Unii Europejskiej.

Działania zaplanowane dla realizacji założeń pierwszego obszaru priorytetowego sprowadzały się do rozwijania inicjatywy Partnerstwa Wschodniego (PW) oraz kontynuacji procesu rozszerzeniowego Unii jako narzędzia stabilizacji w Europie. Propozycja Partnerstwa z krajami postkomunistycznymi, w ramach wschodniego wymiaru Europejskiej Polityki Sąsiedztwa (EPS), pojawiła się na forum unijnym już w czerwcu 2008 r. Wtedy też Rada Europejska przyjęła polsko-szwedzką koncepcję wzmocnienia współpracy wielostronnej UE z jej wschodnimi sąsiadami ${ }^{46}$. Sformułowano rów-

45 PolskaaprzysztośćUniiEuropejskiej.Przemówienie ministrasprawzagranicznych RadosławaSikorskiego wygłoszone 28 listopada 2011 r. w Berlinie, [online] http://www.msz.gov.pl/files/docs/komunikaty/ 20111128BERLIN/radoslaw_sikorski_polska_a_przyszlosc_ue.pdf, 12 IX 2012.

46 Zob. J. Jańczak, B. Przybylska-Maszner, Partnerstwo Wschodnie w ramach polityki wschodniej kluczowym priorytetem polskiej prezydencji, [w:] Priorytety prezydencji Polski..., s. 143. 
nież ramy współpracy dwustronnej w formie umów stowarzyszeniowych z państwami objętymi programem. Do ich grona zaliczono Białoruś, Ukrainę, Mołdawię, Gruzję, Azerbejdżan oraz Armenię. Oficjalna inauguracja Partnerstwa miała miejsce w Pradze w 2009 r., podczas obowiązywania prezydencji czeskiej. Ustanowienie programu oznaczało częściowe przeorientowanie EPS z wymiaru południowego na wymiar wschodni, stając się tym samym alternatywą dla rozwoju Unii dla Śródziemnomorza - projektu wspieranego przez Francję i pozostałe państwa basenu Morza Śródziemnego.

Skierowanie uwagi oraz przeznaczenie większych środków pomocowych UE na potrzeby jej wschodnich sąsiadów miało znaczenie strategiczne dla strony polskiej. Wspieranie przemian demokratyzacyjnych, stabilizacji politycznej oraz rozwoju gospodarczego bezpośrednio za naszą wschodnią granicą leży w interesie polskiej racji stanu. Działania na rzecz wzmacniania współpracy z państwami Europy Wschodniej znalazły swoje odzwierciedlenie w organizacji II Szczytu PW w Warszawie, na którym przyjęto deklarację pogłębienia integracji krajów partnerskich z UE, m.in. poprzez zapowiedź stworzenia strefy wolnego handlu (DCFTA) czy ustanowienia reżimu bezwizowego. Dzięki staraniom strony polskiej udało się doprowadzić do sfinalizowania negocjacji umowy stowarzyszeniowej UE-Ukraina w grudniu $2011 \mathrm{r}^{47}$ Pomimo tych osiągnięć przyszłość inicjatywy PW wciąż jest niepewna. Podczas szczytu w Warszawie nie udało się zagwarantować jasnej perspektywy członkostwa krajom Partnerstwa, natomiast podpisanie umowy stowarzyszeniowej z Ukrainą zostało odłożone w czasie.

Aktywna postawa Polski w rozwijaniu wschodniego wymiaru EPS nie zdominowała pozostałych celów przewidzianych w ramach priorytetu „Otwarta Europa”. Prezydencja poświęciła równie dużo uwagi kwestii przyszłego rozszerzenia Unii, wspierając europejskie ambicje państw Bałkanów Zachodnich i Turcji oraz doprowadzając do podpisania Traktatu akcesyjnego z Chorwacją. W agendzie działań znalazła się również potrzeba wypracowania nowego podejścia w relacjach z krajami Południowego Sąsiedztwa UE, spowodowana wydarzeniami „arabskiej wiosny” oraz wojną domową w Libii. Elastyczna postawa polskiej dyplomacji oraz dostosowywanie działań do aktualnej sytuacji w najbliższym otoczeniu UE wzmocniły wiarygodność polskiej prezydencji jako przewodnictwa skoncentrowanego na wspólnotowych problemach. Pozwoliło to na uniknięcie reakcji kontrkastomizacyjnych innych państw członkowskich wobec priorytetów o strategicznym dla strony polskiej znaczeniu ${ }^{48}$.

\subsubsection{Europa Bezpieczna}

Realizacja ostatniego z przewidzianych obszarów priorytetowych, „Bezpieczna Europa", odnosiła się do kwestii bezpieczeństwa zewnętrznego państw członkowskich

Przewodnictwo Polski..., s. 171.

48 Działania kontrkastomizacyjne polegają na próbie ograniczenia skuteczności realizacji priorytetów, które są skoncentrowane na osiąganiu wewnętrznych korzyści przez państwo sprawujące prezydencję. Po raz pierwszy pojęcie to zostało użyte do określenia reakcji na próbę dostosowania agendy unijnej do potrzeb fińskiej prezydencji. Por. J. Jańczak, B. Przybylska-Maszner, Partnerstwo Wschodnie..., s. 161. 
oraz jego wymiaru energetycznego. Polska prezydencja przyjęła sobie za cel wzmocnienie zdolności wojskowych oraz możliwości obronnych UE, dążąc jednocześnie do zacieśnienia współpracy na linii UE-NATO. Chęć wypracowania sprawnego mechanizmu konsultacji pomiędzy tymi strukturami można uznać za cel strategiczny polskiej polityki zagranicznej. Perspektywa ustanowienia współpracy operacyjnej oraz wywiadowczej, powstałej na bazie wzajemnych konsultacji, może się w przyszłości okazać niezbędna do zagwarantowania bezpieczeństwa obszaru euroatlantyckiego, w tym również regionu Europy Środkowo-Wschodniej. Podobna konstatacja towarzyszyła próbom wzmocnienia zewnętrznej polityki energetycznej UE. Kluczem do zagwarantowania bezpieczeństwa poszczególnych państw członkowskich w tym aspekcie ma się okazać rozwój infrastruktury energetycznej, pozwalającej na dywersyfikację dostawców, dróg dostępu oraz źródeł energii dla Europy ${ }^{49}$. Polska prezydencja wskazała na potrzebę oparcia polityki energetycznej UE na zasadach solidarności, przejrzystości oraz koordynacji, dostrzegając silniejszą pozycję negocjacyjną UE jako potencjalnego importera energii niż pojedynczych państw członkowskich. Efektem starań w tym zakresie było m.in. doprowadzenie do przyjęcia mandatu Komisji Europejskiej do rozpoczęcia negocjacji z Turkmenistanem i Azerbejdżanem w sprawie budowy gazociągu transkaspijskiego. Realizacja projektu tzw. Południowego Korytarza ma się przyczynić do dywersyfikacji źródeł gazu dla Europy, zapewniając jednocześnie bezpieczeństwo energetyczne unijnym gospodarkom oraz redukując ceny energii ${ }^{5}$. Zgodnie z tymi założeniami spójna polityka energetyczna na zewnątrz UE zagwarantuje trwałe warunki dla jej wewnętrznego rozwoju gospodarczego. Działania w ramach priorytetu „Bezpieczna Europa” można więc uznać za umiejętne połączenie interesu narodowego oraz realizacji unijnej agendy.

$\mathrm{Z}$ omówienia zagadnień priorytetowych polskiej prezydencji można wyciągnąć wniosek, że Rzeczpospolita chce być w przyszłości członkiem silnej i spójnej Unii Europejskiej. Postawa zaprezentowana podczas sprawowania przewodnictwa w Radzie sugeruje, że w polskim interesie jest aktywne uczestnictwo w dalszym procesie integracyjnym oraz dbanie o przestrzeganie zasady solidarności i równego traktowania. W tym aspekcie Polska może kandydować do roli naturalnego lidera oraz wyraziciela głosu nowych państw członkowskich z Europy Środkowo-Wschodniej. Jej potencjał polityczny, ekonomiczny oraz demograficzny zobowiązuje do przyjęcia zdecydowanej i czynnej pozycji na arenie europejskiej, uwzględniającej przy tym potrzeby własnego regionu. Zabieganie o utrzymanie wewnętrznej równowagi pomiędzy państwami „starej” i „nowej” Europy, a także oddalanie groźby fragmentaryzacji Unii na kilka obozów czy biegunów, nie musi oznaczać dążenia do federalizacji jej struktur. Znacznie bardziej pożądane wydaje się wzmacnianie Unii w jej obecnym zakresie, a zatem wykorzystywanie możliwości współpracy wynikających z obowiązujących traktatów, niwelowanie różnic gospodarczo-rozwojowych czy dążenie do dalszej integracji rynków towarów i usług: Trzeba wyzyskać możliwości podpisanych traktatów, tzw. sześciopaku, zrealizować

\footnotetext{
49 Przewodnictwo Polski..., s. 168.

50 Tamże, s. 168.
} 
do końca zasady konfederacji, podążajac za wola narodów, a nie próbując ja na site formowac ${ }^{11}$. Polska może odegrać w tym procesie wiodącą rolę, pod warunkiem odrzucenia jednowymiarowego traktowania członkostwa jako projektu modernizacyjnego czy dziejowej konieczności. Dalsze korzystanie z dobrodziejstw integracji będzie wymagać przyjęcia aktywniejszej postawy, pozwalającej na kształtowanie przyszłości UE wedle wspólnego interesu, a zatem umiejętności pozyskiwania sojuszników oraz sztuki osiągania kompromisów.

\section{PODSUMOWANIE}

Zestawienie przebiegu negocjacji akcesyjnych o członkostwo w UE oraz realizacji priorytetów zaprezentowanych podczas polskiej prezydencji w Radzie pozwala dostrzec przełomową zmianę pozycji Polski w procesie integracji europejskiej. Negocjacje akcesyjne sprowadzały się de facto do biernego zaakceptowania dorobku prawnego Unii przy ustaleniu niezbędnych okresów przejściowych na drodze do jego implementacji. Zadaniem strony polskiej była ochrona narodowych interesów oraz wynegocjowanie najlepszych warunków przyszłego członkostwa. Prowadzenie zaciętych rozmów w obszarach „Polityka konkurencji” i „Rolnictwo” są tego najlepszym przykładem. Podobnie jak ocena wyników negocjacji na podstawie ilości wywalczonych dla Polski okresów przejściowych oraz uzyskanych gwarancji finansowych. Wraz ze wstąpieniem kraju do Unii Europejskiej w maju 2004 r. pojawiła się możliwość współtworzenia dorobku wspólnotowego oraz aktywnego uczestnictwa w polityce europejskiej. Wymagało to przeorientowania postawy wobec dalszej integracji, od pozycji defensywnej, ukierunkowanej na zabezpieczenie własnych interesów w relacjach $z \mathrm{UE}$, do pozycji konstruktywnej, zorientowanej na osiąganie kompromisów oraz podejmowanie inicjatyw $w$ ramach $\mathrm{UE}^{52}$. W przypadku Polski wyrazem tej przemiany była realizacja celów o charakterze wspólnotowym podczas sprawowania przewodnictwa w Radzie.

Obecność w Unii daje Polsce szansę na efektywne prowadzenie polityki zagranicznej oraz stabilizację gospodarczą. Skupienie się na trzech ważnych dziedzinach, a więc Partnerstwie Wschodnim, bezpieczeństwie energetycznym i Wspólnej Polityce Rolnej, powinno zapewnić naszemu krajowi trwałe podstawy dalszego rozwoju gospodarczego i społecznego. Jego osiągnięcie uzależnione jest w dużym stopniu od tego, czy kolejne rządy będą w stanie konsekwentnie realizować tak postawione priorytety. Niezbędne będzie również przekonanie pozostałych członków Unii o ich uniwersalnej wartości. Konstruktywna postawa zaprezentowana podczas sprawowania prezydencji oraz odejście od praktyki wetowania unijnych inicjatyw wydają się działaniami w dobrym

51 P. Kowal, Spór o przysztość Polski w Europie: federacja czy aktywny eurorealizm, Fundacja Kazimierza Pułaskiego, [online] http://pulaski.pl/pl/publikacje/stanowisko-pulaskiego/395-spor-o-przyszlosc-polski-w-europie-federacja-czy-aktywny-eurorealizm.html, 13 IX 2012.

52 Zob. P.M. Kaczynski, The Fifth Enlargement of the EU, Fife Years On: The Case of Poland and the Czech Republic, „Europe Vision” 2008, nr 2, s. 23. 
kierunku. Przyjęcie bardziej aktywnej i otwartej na kompromis pozycji w UE będzie w przyszłości równie pożądane, co stosowanie strategii defensywnej podczas negocjacji akcesyjnych w przeszłości.

\section{BIBLIOGRAFIA}

I. Publikacje książkowe:

Literatura źródłowa:

Agenda 2000. Opinia Komisji Europejskiej o wniosku Polski o cztonkostwo w Unii Europejskiej, „Monitor Integracji Europejskiej” (wydanie specjalne) 1997.

Agenda 2000. Unia Europejska rozszerzona i silniejsza, „Monitor Integracji Europejskiej” (wydanie specjalne) 1997.

EWG-Polska. Umowa w sprawie handlu oraz wspótpracy handlowej i gospodarczej, Dz. U. 1990, nr 38, poz. 214.

Raport na temat rezultatów negocjacji o cztonkostwo Rzeczypospolitej Polskiej w Unii Europejskiej, Rada Ministrów, Warszawa 2012.

Raport w sprawie korzyści i kosztów integracji Rzeczpospolitej Polskiej z Unia Europejską, Rada Ministrów, Warszawa 2000.

Traktat $z$ Nicei, Dz. U. UE C 80 z 10 III 2001.

Uchwata Sejmu RP z dnia 4 lipca 1992 r. w sprawie realizacji Uktadu Europejskiego ustanawiajacego stowarzyszenie między Rzeczpospolitą Polska a Wspólnotami Europejskimi i ich państwami cztonkowskimi, Monitor Polski 1992, nr 23, poz. 165.

Uktad Europejski ustanawiający stowarzyszenie między Rzeczpospolita Polska, z jednej strony, a Wspólnotami Europejskimi i ich państwami cztonkowskimi, z drugiej strony, sporządzony w Brukseli dnia 16 grudnia 1991 r., Dz. U. 1994, nr 11, poz. 38.

Wersja skonsolidowana Traktatu o funkcjonowaniu Unii Europejskiej, Dz. U. UE C 83 z 30 III 2010, art. 107, ust. 1.

Wersja Skonsolidowana Traktatu o Unii Europejskiej, Dz. U. UE C 83 z 30 III 2010, art. 1.

White Paper: Preparation of the Associated Countries of Central and Eastern Europe for Integration into the Internal Market of the Union, $\operatorname{COM}(95) 163,1995$.

\section{Literatura pomocnicza:}

- monografie i opracowania:

Polska i Unia Europejska. Stan obecny i wyzwania na przysztość, red. U. Płowiec, Warszawa 2000. Roszkowski W., Najnowsza historia Polski 1980-2002, Warszawa 2003.

\section{- prace zbiorowe:}

Gospodarka Polski w latach 1990-2000, Ministerstwo Gospodarki, Warszawa 2001.

Opinie o integracji Polski z Unia Europejską. Komunikat z badań, Centrum Badań Opinii Społecznej, Warszawa 2002.

Opinie o skutkach integracji Polskiz Unia Europejska iprzebiegu negocjacji akcesyjnych. Komunikat z badań, Centrum Badań Opinii Społecznej, Warszawa 2000. 
- rozdziały w pracach zbiorowych:

Czachór Z., Prezydencja w Unii Europejskiej i jej priorytety, [w:] Priorytety prezydencji Polski $w$ Radzie Unii Europejskiej. Analiza politologiczna, red. Z. Czachór, T.R. Szymczyński, Warszawa 2011.

Fiszer J.M., Negocjacje i perspektywy cztonkostwa Polski w Unii Europejskiej, [w:] tenże, Unia Europejska a Polska. Dziś i jutro, Torun 2004.

Jańczak J., Przybylska-Maszner B., Partnerstwo Wschodnie w ramach polityki wschodniej kluczowym priorytetem polskiej prezydencji, [w:] Priorytety prezydencji Polski $w$ Radzie Unii Europejskiej. Analiza politologiczna, red. Z. Czachór, T.R. Szymczyński, Warszawa 2011.

Nowak A.Z., Milczarek D., Proces integracji Polski z Unią Europejska, [w:] Europeistyka w zarysie, red. tychże, Warszawa 2006.

Zombirt J., Unia Europejska wobec kryzysu finansowego i gospodarczego, [w:] tejże, Mechanizmy rynku wewnętrznego Unii Europejskiej, Warszawa 2011.

- artykuły w czasopismach naukowych:

Kaczynski P.M., The Fifth Enlargement of the EU, Fife Years On: The Case of Poland and the Czech Republic, „Europe Vision” 2008, nr 2.

\section{Publikacje elektroniczne:}

\section{Literatura źródłowa:}

Obwieszczenie Państwowej Komisji Wyborczej z dnia 9 czerwca 2003 r. o wyniku ogólnokrajowego referendum $w$ sprawie wyrażenia zgody na ratyfikacje Traktatu dotyczacego przystapienia Rzeczypospolitej Polskiej do Unii Europejskiej, Dz. U. 2003, nr 103, poz. 953.

Polska a przysztość Unii Europejskiej. Przemówienie ministra spraw zagranicznych Radosława Sikorskiego wygłoszone 28 listopada 2011 r. w Berlinie, [online] http://www.msz.gov.pl/ files/docs/komunikaty/20111128BERLIN/radoslaw_sikorski_polska_a_przyszlosc_ue.pdf.

Program polskiej prezydencji w Radzie Unii Europejskiej, Ministerstwo Spraw Zagranicznych, Warszawa2011,[online]http://pl2011.eu/sites/default/files/users/shared/o_prezydencja/ program_polskiej_prezydencji_w_radzie_ue.pdf.

Przewodnictwo Polski w Radzie Unii Europejskiej. Raport końcowy z przygotowania i sprawowania prezydencji, Ministerstwo Spraw Zagranicznych, Warszawa 2002, [online] http:// pl2011.eu/sites/default/files/users/user43/raport_koncowy_-_rm_17.04.2012.pdf.

\section{Literatura pomocnicza:}

- prace zbiorowe:

Partnership for the accession of Poland, EUROPA - EU website, 19 XI 2004, [online] http://europa.eu/legislation_summaries/enlargement/2004_and_2007_ enlargement/ e40106_en.htm.

Polska - Unia Europejska, Ambasada Rzeczypospolitej Polskiej w Caracas, [online] http:// www.caracas.polemb.net/?document $=49$.

Polskie Rolnictwo - Dwa lata po akcesji do UE, Fundacja Programów Pomocy dla Rolnictwa, Warszawa 2006.

The Nobel Peace Prize for 2012, [online] http://www.nobelprize.org/ nobel_prizes/peace/laureates/2012/press.html\#. 
- artykuły w czasopismach naukowych:

KowalP.,SpóroprzysztośćPolskiwEuropie:federacjaczyaktywnyeurorealizm, Fundacja Kazimierza

Pułaskiego, [online] http://pulaski.pl/pl/publikacje/stanowisko-pulaskiego/395-spor-o-przyszlosc-polski-w-europie-federacja-czy-aktywny-eurorealizm.html.

Szulc W., Garbarz B., Paduch J., Przebieg i wyniki restrukturyzacji przemystu stalowego w Polsce, „Prace Instytutu Metalurgii Żelaza” 2011, nr 4, [online] http://www.imz.pl/ Periodyk/2011/11-4-4-Szulc.pdf.

- artykuły prasowe:

Ryba M., Walka o Rzym, walka o euro, „Nasz Dziennik”, 15 XI 2011, [online] http://stary.naszdziennik.pl/index.php?dat=20111115\&typ=po\&id=po13.txt.

Wałęsa L., Druga Japonia, „Tygodnik Powszechny” 2002, nr 30, [online] http://www.tygodnik. com.pl/japonia/index.html.

Marcin CHRUŚCIEL, student II roku europeistyki II stopnia na UJ. Interesuje się społecznymi i kulturowymi aspektami integracji europejskiej, europejską przestrzenią publiczną oraz procesem demokratyzacji w Europie Środkowo-Wschodniej. Brał udział w badaniach nad mniejszością polską na rumuńskiej Bukowinie oraz w projekcie dotyczącym tożsamości środkowoeuropejskiej w Ołomuńcu. Redaktor naczelny „Zeszytów Naukowych Europeistyki”, w których również publikuje. Poza uczelnią zainteresowany kinem oraz sportem - trenuje lekką atletykę.

Karol KLOC, student II roku europeistyki II stopnia na UJ. Interesuje się systemami politycznymi oraz wpływem najnowszych technologii na społeczeństwo. Współtwórca „Zeszytów Naukowych Europeistyki” oraz dziennikarz naukowy, publikuje m.in. w „Gościu Niedzielnym”. Jego pasją są podróże - autostopem i tanimi liniami lotniczymi odwiedził już większość krajów Europy. 